\title{
Understanding Pancreatic Secretion in Type 1 Diabetes
}

\author{
Mirella Hansen De Almeida1 ${ }^{1}$ Alessandra Saldanha De Mattos Matheus² \\ and Giovanna A. Balarini Lima ${ }^{3}$ \\ ${ }^{1}$ Federal University of Rio de Janeiro (UFRJ), \\ ${ }^{2}$ State University of Rio de Janeiro (UERJ) \\ ${ }^{3}$ Fluminense Federal University of Rio de Janeiro (UFF) \\ Brazil
}

\section{Introduction}

Type 1 Diabetes Mellitus (T1DM) is a chronic disease characterized by the immune-mediated destruction of $\beta$ cells of pancreatic islets. Despite the increase of its incidence observed in last decades, it has not been fully elucidated the immunogenetic and environmental factors associated with the initiation and perpetuation of the pancreatic injury $(1,2)$.

The pathogenic process in T1DM begins with insulitis, which progresses and expands so as to be accompanied by cell necrosis. The rate of progression of the lesion is variable and may be related to age at onset of the disease, being faster in cases diagnosed in children (3). When approximately $80-90 \%$ of insulin-secreting cells have been destroyed, T1DM is clinically overt (4).

T1DM patients may have some residual insulin secretion at diagnosis (5-8). Several studies indicate that the loss of functional capacity usually occurs within three to five years. Most patients with long duration of disease do not present clinical evidence of preservation of $\beta$ cells (9-11). However, the conservation of some residual secretion, even insufficient to cure or prevent T1DM from using insulin, has been associated with a better prognosis regarding glycemic control, lower rates of hypoglycemia, diabetic retinopathy and nephropathy (12).

One of the most frequently used method to assess $\beta$ cell function in patients with T1DM is the determination of C-peptide (CP), a molecule secreted by $\beta$ cells in equimolar concentrations with insulin and without significant liver metabolism (13-15). Taking into consideration the potential benefits of preserving a residual insulin secretion in patients with T1DM, experimental treatments have been proposed in order to maintain detectable levels of $\mathrm{CP}$ in these individuals.

Developments in research aiming for the prevention and cure of T1DM, increased the need to elucidate the contributing factors for the maintenance of residual insulin secretion in patients affected by the disease. This is because individuals who still exhibit residual insulin secretion could be ideal candidates for new curative treatments. Furthermore, most studies of pancreatic function in T1DM have been performed in Caucasians and Asians. We do not know whether the results obtained so far can be extrapolated to other ethnic populations (16). 


\section{Type 1 diabetes mellitus (T1DM)}

\subsection{Definition}

T1DM is a chronic disease characterized by the destruction of pancreatic $\beta$ cells, which leads to absolute deficiency in insulin production.

There are two subgroups of T1DM: type 1A, mediated by autoimmune destruction of $\beta$ cells and type 1B, without an identifiable cause and more common among Asian and AfroAmerican people (17).

\subsection{Epidemiology}

The incidence of T1DM is rising in recent decades (18-20). This has been observed mainly in developed countries, mainly among children younger than four years-old $(18,20-22)$. It is estimated that 15 to 30 million people in the world population have the disease with a growth rate of approximately 3-5\% per year $(19,20,23,24)$.

Epidemiological data suggest that 30 to $50 \%$ of T1DM cases may occur after the age of 20 and $50-60 \%$ of these patients were younger than $16-18$ years at diagnosis. The incidence declines throughout the adult life (25-28).

The incidence among men and women is equal. However, there is a predominance of females in populations at low risk for T1DM, while the opposite occurs in high-risk populations (29).

There is also variation in relation to different countries. There is a high incidence in Finland and Sardinia, Italy (36.5 and 36.8 individuals per 100,000, respectively) and low in Germany and Pakistan. In countries like Brazil and Portugal, the incidence of T1DM is intermediate, as shown in Table 1. In Brazil, there is about 8.0 new cases per 100,000 inhabitants (30).

Regarding ethnicity, individuals of Caucasian origin have a higher incidence of T1DM than Hispanic, African, Asian or Indian descendents (31).

\begin{tabular}{|lcc|} 
& \multicolumn{2}{|c|}{ Incidence per 100,000 people } \\
\hline Country & Term & Total \\
Germany & $1990-1994$ & 1.0 \\
Brazil & $1990-1992$ & 8.0 \\
Canada & $1990-1994$ & 24.0 \\
Denmark & $1990-1994$ & 15.5 \\
Spain & $1990-1994$ & 12.5 \\
USA & $1990-1994$ & \\
$\quad$ White & & 16.4 \\
$\quad$ Non-white & $1987-1989$ & 13.3 \\
Finland & $1990-1994$ & 36.5 \\
Italy Sardinia & & \\
$\quad$ Sicily & & 36.8 \\
$\quad$ Lombardy & $1990-1993$ & 11.7 \\
Mexico & $1990-1994$ & 7.2 \\
Norway & 1990 & 1.5 \\
Pakistan & $1990-1994$ & 21.2 \\
Portugal & $1978-1987$ & 0.7 \\
Sweden & & 13.2 \\
\hline
\end{tabular}

Adapted from The WHO Diamond Project Group, 2000 (30).

Table 1. Incidence of T1DM in population under 15 years-old, in different countries. 


\subsection{Etiopathogenesis}

In the pathogenesis of T1DM, the activation of the immune system mediated by T cells plays a central role. This process leads to an inflammatory reaction (insulitis) characterized by infiltration of pancreatic islets by mononuclear cells such as dendritic cells, macrophages, B lymphocytes and CD4 and CD8 $(3,17,32)$. With the progression of inflammatory injury, there is a development of cellular necrosis and cellular immunity seems to be primarily responsible for this process (33).

The pathogenic process that culminates with the onset of T1DM begins with the loss of selftolerance of $\mathrm{T}$ lymphocytes. Self-tolerance is defined as the process in which $\mathrm{T}$ cells or autoreactive $\mathrm{B}$ are eliminated from the body. This can be divided into central and peripheral. The central tolerance is the deletion of autoreactive $\mathrm{T}$ cells in the thymus and requires the presence of autoantigens in thymic environment. Peripheral tolerance mechanisms are responsible for destroying or inhibiting the function of self-reactive cells that crossed the thymic deletion process, through mechanisms such as immunological ignorance, deletion, anergy or immune inhibition (34).

Some of the risk genes for the development of T1DM are responsible for the concentration of insulin within the thymus. Thus, these genes are linked to the process of central tolerance. Moreover, changes in peripheral tolerance may also be related to the etiopathogenesis and the release of super-antigens after viral infections. Typically, the peripheral tolerance would be responsible for the sequestration of these super-antigens mediated by the immune system, which would not lead to lymphocyte activation $(34,35)$. Another mechanism of pancreatic injury is associated with infection as a possible molecular mimicry between viral antigens and autoantigens aggravating the process of insulitis. This molecular similarity could activate autoreactive T lymphocytes and direct them to attack pancreatic cells (34).

Overt T1DM occurs when approximately 80 to $90 \%$ of the $\beta$ cells have been destroyed (4). The rate of progression to classical T1DM symptoms may be related to age of onset of symptoms, being faster in cases diagnosed at young age (3).

The presence of one or more autoantibodies associated with T1DM may precede the onset of clinical disease by months or even years $(28,36,37)$.

T1DM diagnosed in childhood may have autoantibodies to the major antigens of the pancreatic islets detectable in the first two years of life (38). This seems to be a reflection of cellular injury and its cause is not specific (33). The role of B lymphocyte cells in the pathogenesis of T1DM must also be emphasized. Several diseases mediated by $\mathrm{T}$ lymphocytes present B lymphocytes in the process of antigen presentation (39). A recent study revealed that patients with newly diagnosed T1DM treated with Rituximab (monoclonal anti-CD20) showed improvement in clinical and metabolic parameters after selective depletion of B lymphocytes. The explanation for this fact lies on the reduction of antigen presentation mediated by B lymphocytes, or even the reduction of cytokine production in pancreatic or peri-pancreatic lymph nodes. This suggests that B lymphocytes may have a greater role in the pathogenesis of T1DM than previously thought (40).

Although there are many hypotheses about the onset and progression to autoimmunity of T1DM, the definitive mechanism is not fully understood.

\subsection{Autoantibodies}

Production of pancreatic autoantibodies does not appear to be the primary mechanism of destruction of pancreatic islets $(41,42)$. The release of antigen caused by $\beta$ cell destruction leads to its detection by the immune system and immune activation, subsequently causing 
the production of antibodies against pancreatic components. Thus, antibodies appear to be predominantly markers of immune activation and $\beta$ cell destruction, and not the cause itself $(31,33)$.

The first autoantibody isolated was the antibody against the cytoplasm of the pancreatic islet (islet cell cytoplasmic antibody - ICA) and three major autoantibodies contribute to their positivity: the antiglutamic acid decarboxylase (GADA65), antibody against tyrosine phosphatase (anti-IA2, also known as ICA512) and antibodies against glycolipids (43)

The glutamic acid decarboxylase (GADA) is an enzyme involved in the synthesis of $\gamma^{-}$ amino-butiric acid (GABA) in the central nervous system (CNS) and in pancreatic islets. GADA is expressed in all cell types of pancreatic islets, not only in $\beta$ cells. Two isoforms of GADA (GADA64 and GADA67) synthesized in other tissues have also been identified. GADA, used in current assays, detects pancreatic isoform of this enzyme of $65 \mathrm{kd}$ and is found in $70-80 \%$ of newly diagnosed Caucasian. A lower incidence is observed in children younger than 10 years of age $(43,44)$.

After GADA discovery, anti-IA-2 (40 kd) or ICA512, and anti-IA-2 $\beta$ (37 kd), known as phorin $(45,46)$, were identified. Most patients with anti-IA $2 \beta$ also exhibit anti-IA-2. However, about $10 \%$ of T1DM with anti-IA-2 autoantibodies are not the type-2 anti-IA. Until now, anti-IA-2 appears to be the most specific immunological marker of T1DM and is present in 32 to $75 \%$ of the new cases $(47,48)$. Once detected, most individuals concomitantly present positive GADA and anti-insulin (IAA) (28). Another antibody has been identified as IAA. In children diagnosed under 10 years of age, sensitivity of IAA is of 50 to $60 \%$, while in patients between 10 and 30 years sensitivity is of $10 \%(47,48)$. There is cross-reactivity between antibodies produced against endogenous and exogenous insulin and most patients develop IAA after initiation of insulin therapy, even with the use of recombinant analogues. Thus, the measurement of this antibody in the blood is recommended only before or within 5 to 7 days after initiation of insulin therapy (32).

It has been recently described another auto-antigen associated with T1DM - the zinc transporter 8 (zinc transporter 8 - Znt8). Present in $\beta$ cells, the Znt8 is involved in regulating the insulin secretion pathway. It regulates the entry of zinc in the lumen of the granules, where this cation binds to hexamers of insulin. Nearly 60 to $80 \%$ of individuals with newly diagnosed T1DM have antibodies against this antigen $(49,50)$.

Most pancreatic autoantibody titers decline after the diagnosis of the disease, but GADA may remain positive for many years after diagnosis (51). This feature makes it ideal for antibody studies in patients with T1DM of long duration.

Some patients may not have pancreatic autoantibodies detectable at diagnosis. This can be explained by some reasons (5):

1. These patients may have detectable titers in the pre clinical and became negative before diagnosis.

2. Tests available for determination of these autoantibodies were not sensitive enough to detect low titers.

3. There may be yet unidentified antibodies in research conducted so far.

4. This is possibly a case of idiopathic T1DM (type 1B) without autoimmune etiology.

At diagnosis, traditionally it has been estimated that $90 \%$ of children had one or more pancreatic antibody positive. However, with the availability of anti-Znt8, measuring the combination of the four main pancreatic autoantibodies (GADA, IAA, anti-IA2 and antiZnt8) in patients with newly diagnosed T1DM, showed a detection rate of autoimmunity against $\beta$ cells of $98 \%(49,50)$. 


\subsection{Genetic factors associated with T1DM}

Genes from the histocompatibility system HLA (Human Leukocyte Antigen Complex), IDDM 1 - chromosome 6q21.31, are polymorphic and have different amino acid sequences between individuals. They are divided into HLA class I (HLA-A, B and C) and HLA class II (DP, DQ and DR) and both are related to immune response (52).

HLA class II polymorphisms are associated with an increased risk of T1DM. The main risk alleles are HLA DQB1 * 2002 / * 0302 and HLA DR03/04. The DQB1 * 0602 allele is considered protective (5).

Other genes have been associated with the pathogenesis of T1DM, as shown in Table 2, among which are the insulin gene PTPN22 and CTL4 (17,27,53-55).

\begin{tabular}{|c|c|c|}
\hline * IDDM - insulin dependent diabetes & Genetic Product & $\begin{array}{c}\text { Cromossomic } \\
\text { location }\end{array}$ \\
IDDM1 & HLA & $6 \mathrm{p} 21.31$ \\
IDDM2 & Insulin & $11 \mathrm{p} 15.5$ \\
IDDM3 & - & $15 \mathrm{q} .26$ \\
IDDM4 & - & $11 \mathrm{q} 13$ \\
IDDM5 & - & $6 \mathrm{q} 25$ \\
IDDM6 & - & $18 \mathrm{q} 21$ \\
IDDM7 & - & $2 \mathrm{q} 31-31$ \\
IDDM8 & - & $6 \mathrm{q} 27$ \\
IDDM9 & - & $3 \mathrm{q} 21$ \\
IDDM10 & - & $10 \mathrm{p} 11-\mathrm{q} 11$ \\
IDDM11 & - & $14 \mathrm{q} 4.3-14 \mathrm{q} 31$ \\
IDDM12 & - & $2 \mathrm{q} 33$ \\
IDDM13 & - & $2 \mathrm{q} 34$ \\
IDDM14 & - & $6 \mathrm{q} 21$ \\
IDDM15 & - & $10 \mathrm{q} 25.1$ \\
PTPN22 & CTLA-4 10 \\
\hline
\end{tabular}

Adapted from Kelly et al. 2003 (3) and Eisenbarth, 2005 (32).

Table 2. Genes involved in the Pathogenesis of T1DM 


\subsection{Environmental factors associated with T1DM}

Besides genetic susceptibility, exposure to environmental factors is also important for the development of T1DM. Studies suggest that these factors would be responsible for triggering the immune process that leads to $\beta$ cell destruction. Specific viral infectious diseases have been included among the causes $(56,57)$. Some of the viruses suggested as associated with T1DM are Enteroviruses, Coxsackie virus, congenital Rubella. Toxins such as nitrosamines and protein foods such as cow's milk, cereals and gluten are also considered as potential immunological triggers (58-60). Moreover, the presence of multiple infections in early life is associated with a reduced risk for the disease (1).

Recently, there has been a significant increase in diagnosed cases aged younger than four years $(61,62)$. This shift may be explained by increased exposure to environmental factors or the increased prevalence of obesity $(63,64)$.

One of the hypotheses to explain the development of T1DM is the controversial theory of acceleration suggested by Wilkin. It argues that T1DM and type 2 diabetes (T2DM) constitute a single disease and not two distinct comorbidities. The rate of loss of $\beta$ cell mass, associated with three main factors accelerators, would define the disease. The first factor would be the intrinsic potential for high speed apoptosis of $\beta$ cells, essential, but insufficient for the development of DM. The second accelerator would be insulin resistance, a result of obesity and physical inactivity, central link between the two entities. Insulin resistance overtaxes the $\beta$ cell mass already at risk for accelerated apoptosis, contributing to the clinical expression of DM. The third accelerator was present only in individuals with genetic susceptibility to autoimmunity. Individuals with metabolically more active $\beta$ cells, insulin resistance and genetic susceptibility would be more prone to rapid deterioration of functional and clinical expression of T1DM. In the absence of autoimmune accelerator, apoptosis rate would be slower and thus there would be progression to T2DM (65).

\section{Assessment of pancreatic $\beta$ cell function}

A major limitation of studies of T1DM in humans is the inability to measure the mass of $\beta$ cells in vivo, since pancreatic biopsies are associated with high morbidity and mortality. Therefore, indirect methods have been developed. The assessment of pancreatic function was shown to have a rough correlation with the mass of $\beta$ cells used in islet transplantation in patients with $\mathrm{DM}(25)$.

Methods of imaging and nuclear medicine are being studied to assist the measurement of the mass of pancreatic islets and its correlation with insulin production, but with conflicting results (66-68).

The measurement of $\beta$ cell mass does not always correlate with functional capacity. In prediabetes, there can be no proliferation or maintenance of cell mass (69,70). Marchetti et al suggested that patients with T1DM can have $\beta$ cell secretory dysfunction and not just cell destruction (71).

In an attempt to understand the $\beta$ cell function in vivo, it was initially developed a radioimmunoassay for measurement of serum insulin. For years, this was the gold standard for assessing the secretory activity. However, there are several factors limiting the use of serum insulin for the evaluation of pancreatic $\beta$ cell function. The first is that 50 to $60 \%$ of the insulin produced by the pancreas undergoes hepatic metabolism and does not reach the systemic circulation. In addition, the peripheral clearance of insulin is variable and the tests available for their determination do not differentiate insulin, proinsulin, its intermediates 
and the use of exogenous insulin. Another limiting factor is the presence of anti-insulin antibodies (IAA) to interfere in the measurement of serum insulin $(12,72,73)$.

Thus, other means to measure $\beta$ cell function have been developed, and among them the measurement of baseline and/or stimulated CP.

\subsection{C-peptide}

Pancreatic $\beta$ cells secrete, in addition to insulin, proinsulin, conversion intermediates of insulin (proinsulin split) and the connecting peptide (CP) (15).

The pro-insulin is cleaved in the Golgi apparatus of islet cells. This reaction leads to the formation of insulin, $\mathrm{CP}$ and two pairs of basic amino acids. Insulin and the $\mathrm{CP}$ are released into circulation at a ratio of $1: 1$, as well as small amounts of proinsulin and intermediates. The proinsulin sum $20 \%$ of molecules with insulin-immunoreactivity simile, seems to have no metabolic effect, undergoes extra-hepatic metabolism and is excreted exclusively by the kidneys.

The $\mathrm{CP}$ is a connection between the peptide chains $\mathrm{A}$ and $\mathrm{B}$ of proinsulin and facilitates the processing of biologically active insulin in secretory granules of pancreatic islets. After the cleavage of proinsulin, the intact $\mathrm{CP}$ is stored with insulin in these granules and is cosecreted with insulin. For this reason, the $\mathrm{CP}$ can be considered an independent marker of insulin secretion (16). However, in some situations, such as renal failure, the serum concentration of $\mathrm{CP}$ is not proportional to the rate of insulin secretion. About $85 \%$ of $\mathrm{CP}$ is metabolized by the kidneys and the remainder excreted intact in urine. A decrease in renal function leads to reduced metabolism of $\mathrm{CP}$ and elevated serum levels (74)

The CP plasma half-life is of thirty minutes, greater than that of insulin, which is only of four minutes (13-15,75). The normal value of the CP varies from 1.1 to $5.0 \mathrm{ng} / \mathrm{mL}$.

Under standard conditions of measurement, the $\mathrm{CP}$ has been widely accepted as a rough measure of insulin secretion, since it is secreted into the portal circulation in equimolar, concentrations, does not undergo hepatic metabolism, its half-life is longer (30 minutes) and has low cross reactivity with proinsulin and insulin antibodies $(12,76,77)$.

In adverse conditions, such as hyper- or hypoglycemia, $\mathrm{CP}$ concentrations are not proportional to the rate of insulin secretion, and its clearance may vary between different individuals $(78,79)$.

Therefore, at the moment, the most appropriate, accepted and clinically validated method to measure the ability of $\beta$ cell secretion under ideal conditions is the measurement of baseline and/or stimulated CP (76). This stimulation can be done with glucose or insulin secretagogues such as glucagon, standard mixed meal or oral glucose tolerance test with $75 \mathrm{~g}$ of anhydrous glucose (OGTT) (12,80-82).

The standard mixed meal test consists of oral administration of a liquid diet (Sustacal ${ }^{\circledR}$ / Boost) of approximately $500 \mathrm{kcal}$ containing $50 \%$ carbohydrate, $30 \%$ fat and $20 \%$ protein. Blood samples for measurement of blood glucose and CP are collected in fasting and 30,60 and/or 90 minutes after the meal $(76,80)$. This test shows the typical postprandial response of the cell $\beta$ and its interaction with the various hormones secreted during oral feeding. It is the most physiological test among the above cited $(76,83)$.

Oral glucose tolerance test (OGTT) is the determination of glucose, insulin and CP after 10 hours of fasting and 30, 60, 90, 120 minutes after ingestion of $75 \mathrm{~g}$ anhydrous glucose orally administered. It is used to measure glucose tolerance and the residual function of the $\beta$ cell in patients at risk, but has not yet been validated for use in T1DM patients. It is useful to 
predict early changes in glucose metabolism in relatives of T1DM or individuals with positive autoantibodies (76).

The glucagon stimulation test is done by measurement of $\mathrm{CP}$ at baseline, after 8 hours fasting, and 6 minutes after intravenous administration of $1 \mathrm{mg}$ of glucagon, while its maximum concentration is observed $(76,79)$. The most commonly observed side effects are facial flushing and nausea due to decreased gastrointestinal motility (76). The advantages of the glucagon test in relation to the standard meal test are:

1. Faster action, since glucagon is a potent supra-physiological stimulus for insulin secretion, directly and indirectly, also influenced by hyperglycemia (76).

2. Minor influence of glucotoxicity in patients with high glycated hemoglobin (HbA1C) $(76,80)$.

3. Simple technical achievement (76).

4. Good reproducibility between individuals (76).

To avoid inaccuracy in $\mathrm{CP}$ measurement, caution is necessary during blood collection and processing. As the $\mathrm{CP}$ is a small molecule, linear and prone to degradation by proteolytic enzymes blood samples should be cleared by centrifugation for a short period of time (not more than a few hours). Palmer et al suggest that this is done within one month after collection because immunoreactivity falls with prolonged blood storage generating falsely lower results (84). This time, however, it is not well defined (12). Until the proper measurement, the serum should be stored $-80^{\circ} \mathrm{C}$.

Changes in blood glucose are factors that acutely interfere with the measurement of serum $\mathrm{CP}$ and can underestimate the ability of secretion. The Immunology of Diabetes Society has established that the glucagon test must be conducted during fasting and with glucose levels between 70 and $200 \mathrm{mg} / \mathrm{dL}$. The optimal level of blood glucose in these patients is around $126 \mathrm{mg} / \mathrm{dL}$. Hypoglycemia $(<70 \mathrm{mg} / \mathrm{dL}$ ) inhibits the insulin response while acute hyperglycemia $(>200 \mathrm{mg} / \mathrm{dL}$ ) may potentiate the secretory response or inhibit it. On the other hand, chronic hyperglycemia can reduce $\beta$ cell function due to the phenomenon of glucotoxicity (85-86). Moreover, high glucose concentrations have been shown to damage $\beta$ cells in vitro and in vivo, compromising insulin secretion (87).

The characteristics of the methods used to quantitate the $\mathrm{CP}$ must be well defined. The presence of cross-reactivity with proinsulin and its intermediate results in falsely elevated $\mathrm{CP}$ concentrations. In general, it is expected that the rate of cross-reactivity of a method is less than $10 \%(12)$.

\subsection{Role of the pancreatic $\beta$ cell in T1DM}

In T1DM, there is a progressive loss of the ability of insulin secretion. During the process of destruction of pancreatic $\beta$ cells, the first abnormality observed in the preclinical phase is the loss of first phase insulin secretion - FPIR, First phase insulin release $(31,88)$. The FPIR is the sum of the plasma insulin at 1 and 3 minutes after the glucose load during an intravenous glucose tolerance test (76). Moreover, impairment in glucose tolerance test has been correlated with an increased risk of progressing from preclinical to clinical diabetes (4).

One of the first authors who studied $\beta$ cell function in diabetic patients and healthy controls was OK Faber et al in 1977. He compared measurements of the CP after the standard meal and after glucagon (1 mg intravenous) and noticed that the $\mathrm{CP}$, at baseline and after fasting and stimulation with glucagon, was higher in healthy controls when compared to patients with T1DM (79). Subsequently, it was identified that individuals with T1DM may have 
some residual insulin secretion at diagnosis especially in cases diagnosed in adulthood (5-8, 89).

The loss of this residual secretion usually occurs within three to five years after the diagnosis (86). Patients with long duration of illness tend not to have CP secretory reserves, demonstrating the exhaustion of pancreatic secretion (9-11). However, Meier et al demonstrated the preservation of $\beta$ cells secreting insulin in most patients with T1DM evaluated in histopathological studies (90). In addition, Keenan and colleagues demonstrated detectable levels of CP in 18\% of individuals with T1DM for over 50 years and absence of chronic complications of the disease (91).

The reason why some $\beta$ cells are maintained for years after diagnosis of T1DM remains unclear. It is possible that some cells are not equally susceptible to destruction or even that the destructive process is attenuated over the years. Another possibility to explain this persistence would be a recovery in $\beta$ cell by replication, which seems unlikely. Another explanation is that some cells could be inactive and not destroyed and recover their function over time (92).

\subsubsection{Factors influencing the residual insulin secretion and $C P$}

The rate of decline of pancreatic function in T1DM is heterogeneous, ranging from 13 to $58 \%$ in the first year after diagnosis (84). Some factors such as age at diagnosis and sex seem to influence this fall. Association between residual pancreatic function and female sex has also been found (93). Karjalainen et al reported that T1DM that begins in adulthood (20 to 55.8 years old) is characterized by a longer asymptomatic period before diagnosis and better preservation of residual $\beta$ cell function than T1DM beginning in childhood $(5,16,94)$.

Some studies have shown that baseline serum CP levels in patients diagnosed in adulthood and post-pubertal period are higher than in those diagnosed in the pre-puberty $(7,8,12)$. This fact indicates a greater destruction of $\beta$ cells in younger people. However, there could be a change in $\mathrm{CP}$ levels according to age. According to Palmer JP et al, the serum CP levels in adulthood are around 0.6 to $1.3 \mathrm{nmol} / \mathrm{L}$ during puberty between 0.3 and $0.9 \mathrm{nmol} / \mathrm{L}$ and in pre-pubertal $<0.2 \mathrm{nmol} / \mathrm{L}(12)$.

In the Diabetes Control and Complications Trial (DCCT), patients with short disease duration ( $\leq$ 5 years) had a CP after the stimulus with mixed meal detectable (greater than $0.2 \mathrm{nmol} / \mathrm{L}$ ) in $33 \%$ of those with $<18$ years of age and $48 \%$ in adults (10). Stimulated CP $>0.2 \mathrm{pmol} / \mathrm{mL}$ was found in $3 \%$ of children and $8 \%$ of adults with long duration of illness ( $>5$ years). Basal and stimulated $\mathrm{CP}$ were negatively correlated with disease duration (80).

The presence of antibodies is another predictor of reduction in $\beta$ cell function. High levels of ICA were associated with a faster decrease in the secretion of CP (81). Aimed to modulate the immune system and prevent the destruction of $\beta$ cells, studies using vaccination against GADA showed some preservation of the $\mathrm{CP}$, although it did not change the needs of insulin $(95,96)$.

There is evidence that intensive glucose control can reduce, at least temporarily, the failure of insulin secretion in T1DM. However, it is possible that the maintenance of some residual secretion facilitates the achievement of adequate metabolic control (20). The mechanisms by which intensive insulin prolongs the $\beta$-cell function in T1DM can be due to reduced glucotoxicity or by direct action in the autoimmune destruction (97). 


\subsubsection{Impact of maintenance of residual insulin secretion and PC}

The persistence of detectable CP serum levels, especially in patients with long duration of disease, may have clinical importance. Some studies have shown that this is a prognostic factor for improved glycemic control, lower frequency of hypoglycemia, retinopathy and diabetic nephropathy $(8,80,98)$. So far, the main information about the importance of preservation of some residual secretion in the development of chronic complications, glycemic control and incidence of hypoglycemia T1DM were obtained from the DCCT (8). In the DCCT, the intensive glucose control significantly reduced the loss of $\beta$ cell function in relation to conventional treatment. Furthermore, patients with $\mathrm{CP} \geq 0.2 \mathrm{nmol} / \mathrm{L}$ in the intensive treatment group had lower $\mathrm{HbA1C}$ at baseline and through the four year followup period (8).

The presence of a residual capacity for insulin secretion has also been associated with a reduced risk of hypoglycemia. Data from the DCCT showed that patients with stimulated $\mathrm{CP} \geq 0.2 \mathrm{nmol} / \mathrm{L}$ for at least one year had the prevalence of hypoglycemia reduced in $30 \%$. Among patients in intensive control group, the risk of hypoglycemia was three times lower in those who remained detectable $\mathrm{CP}$ than in others. In the conventional group, this difference was not observed (8).

In relation to chronic complications, the DCCT showed that patients with T1DM and undetectable levels of $\mathrm{CP}(<0.04 \mathrm{nmol} / \mathrm{L})$ had 4.6 times greater chance of progression to diabetic retinopathy and 4.4 times greater chance of developing microalbuminuria in relation to others (8).

Some authors found no association between the frequency of chronic complications and residual $\beta$ cell function. Klein and colleagues studied the relationship between serum levels of $\mathrm{CP}$ and severity of diabetic retinopathy in different types of diabetes in the Wisconsin Epidemiologic Study of Diabetic Retinopathy. Young subjects with T1DM using insulin did not present any association between $\mathrm{CP}$ levels and the frequency or severity of diabetic retinopathy (99). Winocour et al, on the other hand, found an association between the presence of residual secretion of $\mathrm{CP}$ and reduced risk of proliferative diabetic retinopathy in T1DM but no correlation to peripheral neuropathy or autonomic, hypertension, nephropathy or coronary heart disease (100).

Other studies also found no influence of $\mathrm{CP}$ stimulated with the development of retinopathy, neuropathy and/or microalbuminuria in T1DM. However, these studies included a small number of patients, with short time for monitoring and/or few chronic complications (100-102).

In the pathological study of Meier et al, the number of $\beta$ cells found in patients with T1DM was not associated with the disease duration, but rather with glycemic control, being higher at lower blood glucose levels (90).

Today, the role of the $\mathrm{CP}$ only as a marker of insulin secretion is questionable. Some suggests that it may also have a direct action on target organs of chronic complications of T1DM (84). Potential actions of the CP include: improvement in nerve conduction velocity, improving the sensory and autonomic nerve function, improvement in cardiac function, decreased microalbuminuria; stimulation of the activity of nitric oxide synthase (eNOS) inhibition of smooth muscle cells proliferation; and decreased signal transduction of NF-k $\beta$ (nuclear factor kappa-light-chain-enhancer of activated B cells) with reduced inflammation. These findings have been observed in vitro and in clinical studies in animals and humans with T1DM (84). 


\subsubsection{Methods of preserving pancreatic function}

The need for insulin and/or progression of pancreatic $\beta$ cell damage can be avoided by preserving the ability of insulin secretion. The maintenance of some residual function, even if insufficient to avoid insulin therapy may have important advantages in better metabolic control and lower risk of chronic complications as previously described $(8,84)$.

The DCCT showed that intensive insulin therapy can reduce the progression of $\beta$ cell damage, with positive effects for up to 6 years after diagnosis (8). Brown et al in their study also confirmed this benefit (103). Intensive insulin therapy may promote survival of $\beta$ cells, reducing the metabolic demand and glucotoxicity.

Immunosuppressive therapy, such as cyclosporine, azathioprine, prednisone, and antithymocyte globulin, aiming for depletion and inactivation of $\beta$ cells, were used in newly diagnosed patients, but with limited efficacy and temporary effects due to its toxicity (104).

Immunomodulators, such as anti-CD3 monoclonal antibodies, used in newly diagnosed T1DM also allowed the maintenance of the secretion of $\mathrm{CP}$ for one to two years with low toxicity, and benefits in glycemic control (105-107). After 48 months of follow up, patients who received the monoclonal antibodies anti-CD3 had lower daily insulin requirements, with improved $\mathrm{A} 1 \mathrm{C}$ and glycemic variations smaller than the control. The best results have been found in individuals under the age of 27 years and with higher $\mathrm{CP}$ at baseline (108).

The induction of immunological tolerance to self antigens such as GAD, insulin and oral heat shock protein 60 (HSP60) has been tried with controversial results in preservation of islet function $(104,109,110)$.

Another measure that has been tested for secondary prevention of T1DM is the autologous non-myeloablative hematopoietic stem cell transplant. Voltarelli and colleagues conducted this transplant in 15 newly diagnosed patients with T1DM. Five patients have remained insulin free for up to 21 months and seven remained for more than six months without use of exogenous insulin (111). Despite the low rate of complications reported, there is a potential risk for more serious effects related to immunosuppression. $(107,110)$. Mesenchymal stem cell therapies and combination of multiple immunomodulatory drugs are currently under study.

Several studies aiming at the preservation of $\beta$ cell mass are being conducted, with a main goal: search for the cure of T1DM. The attempt to preserve $\beta$ cell function even if insufficient to cure the disease, can be useful in the prevention of microvascular complications, improves glycemic control and reduced the frequency of hypoglycemic events $(7,8,12,98)$.

In summary, we tried to emphasize some aspects of the natural history of T1DM. At first, a large mass of beta cell function is lost between the period from the surveillance diagnosis to the period of overt T1DM. Then, residual beta cell function results in better glycemic control and less microvascular complications. The rate of progression of beta cell failure may be due to several factors such as underlying genetic predisposition, age of the patient and metabolic control. Finally, $\mathrm{CP}$ has its role on diagnosis reserve of beta cell mass and higher levels are associated to a better glycemic control and preservation of pancreatic function. Moreover, interventions that are being held nowadays are clinically important to quality of life, mortality and morbidity of patients with T1DM.

\section{References}

[1] Atkinson MA et al. Type 1 Diabetes: New Perspectives On Disease Pathogenesis And Treatment. Lancet 2001; 358: 221-229. 
[2] Libman IM, Laporte RE. Changing Trends In Epidemiology Of Type 1 Diabetes Mellitus Throughout The World: How Far Have We Come And Where Do We Go From Here. Pediatr Diabetes 2005; 6(3): 119-121.

[3] Kelly MA, Rayner ML, Mijovic CH et al. Molecular Aspects Of Type 1 Diabetes. Mol Pathol 2003; 56 (1): 1-10.

[4] Knip M, Kukko M, Kulmala P et al. Humoral Beta - Cell Autoimmunity In Relation To HLA-Defined Disease Susceptibility In Preclinical And Clinical Type 1 Diabetes. Am J Med Genetics 2002; 115: 48-54.

[5] Sabbah E, Savola K, Ebeling T et al. Genetic, Autoimmune And Clinical Characteristics Of Childhood And Adult Onset Type 1 diabetes. Diabetes Care 2000; 23 (9):13261332.

[6] Effects Of Age, Duration And Treatment Of Insulin-Dependent Diabetes Mellitus On Residual Beta-Cell Function: Observations During Eligibility Testing For The Diabetes Control And Complications Trial (DCCT). The DCCT Research Group. J Clin Endocrinol Metab 1987; 65: 30-36.

[7] The Diabetes Control And Complications Trial Research Group: The Effect Of Intensive Treatment In Diabetes On The Development And Progression Of Long-Term Complications On Insulin-Dependent Diabetes Mellitus. N Engl J Med 1993; 329: 977-986.

[8] The Diabetes Control And Complications Trial Research Group: The Effect Of Intensive Therapy On Residual Beta-Cell Function In Patients With Type 1 Diabetes In The Diabetes Control And Complications Trial. Ann Intern Med 1998; 128: 517-523.

[9] Cravarezza P, Radaeli E, Toffoli C et al. Discrimination Of Type 1 From Insulin-Treated Type II Diabetic Patients By C Peptide Measurement. Acta Diabetol Lat 1986; 23 (4): 345-350.

[10] Gottsater A, Landin-Olsson M, Fernlund P et al. Beta-Cell Function In Relation To Islet Cell Antibodies During The First 3 Years After Clinical Diagnosis Of Diabetes In Type II Diabetic Patients. Diabetes Care 1993; 16(6): 902-910.

[11] Ahn CW, Kim HS, Nam JH et al. Clinical Characteristics, GAD Antibody (GADA) And Change Of C-Peptide In Korean Young Age Of Onset Diabetic Patients. Diabet Med 2002; 19(3): 227-233.

[12] Palmer JP, Fleming GA, Greenbaum CJ et al. C-Peptide Is The Appropriate Outcome Measure For Type1 Diabetes Clinical Trials To Preserve Beta Cell Function - ADA Workshop Report. Diabetes 2004; 53: 250-264.

[13] Polonsky KS, Jaspan J, Pugh W, Cohen D, Schneider M, Schartz T, Moossa AR, Tager H, Rubenstein AH. Metabolism Of C-Peptide In The Dog; In Vivo Demonstration Of The Absence Of Hepatic Extraction. J Clin Invest 1983; 72: 1114-1123.

[14] Polonsky KS, Pugh W, Jaspan JB, Cohen DM, Karrisson T, Tager HS, Rubenstein AH. CPeptide And Insulin Secretion: Relationship Between Peripheral Concentrations Of C-Peptide And Their Secretion Rates In The Dog. J Clin Invest 1984; 74:1821-1829.

[15] Bratusch-Marrain PR, Waldhausl WK, Gasic S, Hofer A. Hepatic Disposal Of Biosynthetic Human Insulin And Porcine Proinsulin In Humans. Metabolism 1984; 33: 151-157.

[16] Rodacki M, Zajdenverg L, Tortora RP et al. Characteristics Of Childhood And AdultOnset Type 1 Diabetes In A Multi-Ethnic Population. Diab Res Clin Pract 2005; 69: 22-28. 
[17] Daneman D. Type 1 Diabetes. Lancet 2006; 367: 847-858.

[18] Gale EA. The Rise Of Childhood Type1 Diabetes In The 20th Century. Diabetes 2002; 51(12): 3353-3361.

[19] Secular Trends In Incidence Of Childhood IDDM In 10 Countries. Diabetes Epidemiology Research International Group. Diabetes 1990; 39(7): 858-864.

[20] Variation And Trends In Incidence Of Childhood Diabetes In Europe. EURODIAB ACE Study Group. Lancet 2000; 355(9207): 873-876.

[21] Rewers M, Norris JM, Eisenbarth GS et al. Beta-Cell Autoantibodies In Infants And Toddlers Without IDDM Relatives: Diabetes Autoimmunity Study In The Young (DAISY). J Autoimmun 1996; 9(3): 405-410.

[22] Onkamo P, Vaananen S, Karvonen $M$ et al. Worldwide Increase In Incidence Of Type I Diabetes - The Analysis Of The Data On Published Incidence Trends. Diabetologia 1999; 42(12): 1395-1403.

[23] Rosenbauer J, Herzig P, Von KR et al. Temporal, Seasonal, And Geographical Incidence Patterns Of Type 1 Diabetes Mellitus In Children Under 5 Years Of Age In Germany. Diabetologia 1999; 42(9): 1055-1059.

[24] Karvonen M, Pitkaniemi J, Tuomilehto J. The Onset Age Of Type 1 Diabetes In Finnish Children Has Become Younger. The Finnish Childhood Diabetes Registry Group. Diabetes Care 1999; 22(7): 1066-1070.

[25] Laakso M, Pyorala K. Age Of Onset And Type Of Diabetes. Diabetes Care 1985; 8: 114117.

[26] Molbak AG, Christau B, Marner B et al. Incidence Of Insulin-Dependent Diabetes Mellitus In Age Groups Over 30 Years In Denmark. Diabetic Med 1994; 11: 650-655.

[27] Devendra D, Liu E, Eisenbarth GS. Type 1 Diabetes: Recent Developments. BMJ 2004; 328: 750-754.

[28] Barker JM, Barriga KJ, Yu L, et al. Prediction Of Autoantibody Positivity And Progression To Type 1 Diabetes: Diabetes Autoimmunity Study In The Young (DAISY). J Clin Endocrinol Metab 2004; 89: 3896-3902.

[29] Karvonen M, Pitkaniemi M, Pitkaniemi J et al. Sex Difference In The Incidence Of Insulin-Dependent Diabetes Mellitus: An Analysis Of The Recent Epidemiological Data. World Health Organization DIAMOND Project Group. Diabetes Metab Rev 1997; 13(4): 275-291.

[30] Karvonen M, Viik-Kajander M, Moltchanova E et al. Incidence Of Childhood Type 1 Diabetes Worldwide. Diabetes Mondiale DIAMOND Project Group. Diabetes Care 2000; 23(10): 1516-1526.

[31] Diagnosis And Classification/ Pathogenesis. In: Bode BW. Medical Management Of Type I Diabetes. 4a Ed. Alexandria (Virginia): American Diabetes Association; 2004. P. 4-18.

[32] Eisenbarth GS. Type 1 Diabetes Mellitus. In: Kahn CR, Weir GC, King GL, Moses AC, Smith RJ, Jacobson AM. Joslin's Diabetes Mellitus. 14a Ed. Boston, MA: Lippincott Williams \& Wilkins; 2005. Cap. 23, P.399-424.

[33] Baekkeskov S, et al. Auto-Antibodies In Newly Diagnosed Diabetic Children Immunoprecipitate Human Pancreatic Islet Cell Proteins. Nature 1982; 298: 167 169.

[34] Kamradt,T.; Mitchison, N.A. Tolerance And Autoimmunity. N.Engl.J.Med 2001; 344(9): 655-664. 
[35] Vafiadis, P. et al. Insulin Expression In Human Thymus Is Modulated By Ins Vntr Alleles At The Iddm2 Locus. Nat.Genet 1997; 15(3): 289-292.

[36] Krischer JP, Cuthbertson DD, Yu L, et al. Screening Strategies For The Identification Of Multiple Antibody-Positive Relatives Of Individuals With Type 1 Diabetes. J Clin Endocrinol Metab 2003; 88: 103-108.

[37] Maclaren N, Lan M, Coutant R, et al. Only Multiple Autoantibodies To Islet Cells (ICA), Insulin, GAD65, IA-2 And IA-2beta Predict Immune-Mediated (Type 1) Diabetes In Relatives. J Autoimmun 1999; 12: 279-287.

[38] Lohmann T, Sessler J, Verlohren HJ et al. Distinct Genetic And Immunological Features In Patients With Insulin-Dependent Diabetes Below And Above Age 40 At Onset. Diabetes Care 1997; 20: 524-529.

[39] Rivera A et al. Role Of B Cells As Antigen-Presenting Cells In Vivo Revisited: AntigenSpecific B Cells Are Essential For T Cell Expansion In Lymph Nodes And For Systemic T Cell Responses To Low Antigen Concentrations. Int Immunol; 13(12): 1583-1593.

[40] Pescovitz MD et al. Rituximab, B-Lymphocyte Depletion, And Preservation Of BetaCell Function. N Engl J Med 2009; 361(22): 2143-2152.

[41] Acherbach P, Bonifacio E, Koczwara K, Ziegler AG. Natural History Of Type 1 Diabetes. Diabetes 2005; 54(2): S25-S31.

[42] Pihoker C, Gilliam LK, Hampe CS et al. Autoantibodies In Diabetes. Diabetes 2005; 54(2): S52-S61.

[43] Yu L, Eisenbarth GS. Humoral Autoimmunity - Chapter 10, 2008. Em: <Http://Www.Uchsc.Edu/Misc/Diabetes/Books/Type1/Type1_Ch10.Html>. Acesso Em: Jun 2010.

[44] Winter WE, Harris N, Schatz D. Type 1 Diabetes Islet Autoantibody Markers. Diabetes Technol Ther 2002; 4(6): 817-39.

[45] Payton MA, Hawkes CJ, Christie MR. Relationship Of The 37,000- And 40,000-M(R) Tryptic Fragments Of Islet Antigens In Insulin-Dependent Diabetes To The Protein Tyrosine Phosphatase-Like Molecule IA-2 (ICA512). J Clin Invest 1995; 96(3): 15061511.

[46] Lu J, Li Q, Xie H et al. Identification Of A Second Transmembrane Protein Tyrosine Phosphatase, IA-2beta, As An Autoantigen In Insulin-Dependent Diabetes Mellitus: Precursor Of The 37-Kda Tryptic Fragment. Proc Natl Acad Sci USA 1996; 93(6): 2307-2311.

[47] Graham J, Hagopian WA, Kockum I et al. Genetic Effects On Age-Dependent Onset And Islet Cell Autoantibody Markers In Type 1 Diabetes. Diabetes 2002; 51(5): 1346-1355.

[48] Kawasaki E, Takino H, Yano M et al. Autoantibodies To Glutamic Acid Decarboxylase In Patients With IDDM And Autoimmune Thyroid Disease. Diabetes 1994; 43(1): 80-86.

[49] Eisenbarth GS, Jeffrey J. The Natural History Of Type 1A Diabetes. Arq Bras Endrocrinol Metab 2008;52(2): 146-155.

[50] Wenzlau JM et al. The Cation Efflux Transporter Znt8 (Slc30A8) Is A Major Autoantigen In Human Type 1 Diabetes. Proc Natl Acad Sci 2007; 104(43): 17040-17045.

[51] Zimmet PZ. The Pathogenesis And Prevention Of Diabetes In Adults. Diabetes Care 1995; 18(7): 1050-1064. 
[52] Reijonen H, Concannom. Genetics Of Type 1 Diabetes. In: Kahn CR, Weir GC, King GL, Moses AC, Smith RJ, Jacobson AM. Joslin's Diabetes Mellitus. 14a Ed. Boston, MA: Lippincott Williams \& Wilkins; 2005. Cap. 21, P.355-370.

[53] Redondo MJ, Fain PR, Eisenbarth GS. Genetics Of Type 1A Diabetes. Recent Prog Horm Res 2001; 56: 69-89.

[54] Lambert AP, Gillespie KM, Thomson G, et al. Absolute Risk Of Childhood-Onset Type 1 Diabetes Defined By Human Leukocyte Antigen Class II Genotype: A PopulationBased Study In The United Kingdom. J Clin Endocrinol Metab 2004; 89: 4037-4043.

[55] Anjos S, Polychronakos C. Mechanisms Of Genetic Susceptibility To Type 1 Diabetes: Beyond HLA. Mol Genet Metab 2004; 81: 187-195.

[56] Akerblom HK, Vaarala O, Hyooty $\mathrm{H}$ et al. Environmental Factors In The Etiology Of Type 1 Diabetes. Am J Med Genet 2002; 115: 18-29.

[57] Hyoty H, Hiltunen M, Knip M et al. The Childhood Diabetes In Finland (Dime) Study Group. A Prospective Study Of The Role Of Coxsackie B And Other Enterovirus Infections In The Pathogenesis Of IDDM. Diabetes 1995; 44: 652-657.

[58] Lammi N, Karvonen M, Tuomilehto J. Do Microbes Have A Causal Role In Type 1 Diabetes? Med Sci Monit 2005; 11: 63-69.

[59] Robles DT, Eisenbarth GS. Type 1A Diabetes Induced By Infection And Immunization. J Autoimmun 2001; 16: 355-362.

[60] Helgason T, Jonasson MR. Evidence For A Food Additive As A Cause Of Ketosis-Prone Diabetes. Lancet 1981; 318: 716-720.

[61] Dahlquist G, Mustonen L. Analysis Of 20 Years Of Prospective Registration Of Childhood Onset Diabetes Time Trends And Birth Cohort Effects. Swedish Childhood Study Group. Acta Paediatr 2000; 89: 1231-1237.

[62] Weets I, De Leeuw IH, Du Caju MV, et al. The Incidence Type1 Diabetes In The Age Group 0-39 Years Has Not Increased In Antwerp (Belgium) Between 1989 And 2000. Diabetes Care 2002; 25: 840-846.

[63] Tremblay MS, Willms JD. Secular Trends In The Body Mass Index Of Canadian Children. CMAJ 2000; 163: 1429-1433.

[64] Chinn S, Hughes JM, Rona RJ. Trends In Growth And Obesity In Ethnic Groups In Britain. Arch Dis Child 1998; 19: 162-166.

[65] Wilkin TJ. The Accelerator Hypothesis: Weight Gain As The Missing Link Between Type 1 And Type II Diabetes. Diabetologia 2001; 44: 914-922

[66] Alanentalo T, Rnblad AH, Mayans S et al. Quantification And Three-Dimensional Imaging Of The Insulitis-Induced Destruction Of _-Cells In Murine Type 1 Diabetes. Diabetes 2010; 59: 1756-1764.

[67] Meier JJ, Menge BA, Breuer T et al. Functional Assessment Of Pancreatic Cell Area In Humans. Diabetes 2009; 58: 1595-1603.

[68] Ueberberg S, Meier JJ, Waengler C et al. Generation Of Novel Single-Chain Antibodies By Phage-Display Technology To Direct Imaging Agents Highly Selective To Pancreatic - Or -Cells In Vivo. Diabetes 2009; 58: 2324-2334

[69] Screenan S, Pick AJ, Levisetti M et al. Increased Beta-Cell Proliferation And Reduced Mass Before Diabetes Onset In The Non obese Diabetic Mouse. Diabetes 1999; 48: 989-996. 
[70] Shimada A, Charlton B, Taylor-Edwards C, Fathman CG: Beta-Cell Destruction May Be A Late Consequence Of Autoimmune Process In Non Obese Diabetic Mice. Diabetes 1996; 45: 1063-1067.

[71] Marchetti P, Dotta F, Zhiong L, et al. The Function Of Pancreatic Islets Isolated From Type 1 Diabetic Patient. Diabetes Care 2000; 23: 701-703.

[72] Lucinio-Paixao J, Polonsky KS, Given BD et al. Ingestion Of A Mixed Meal Does Not Affect The Metabolic Clearance Rate Of Biosynthetic Human C-Peptide. J Clin Endocrinol Metab 1983; 63: 401-403.

[73] Gumbiner B, Polonsky KS, Beltz WF et al. Effects Of Weight Loss And Reduces Hyperglycemia On The Kinetics Of Insulin Secretion In Obese Non-Insulin Dependent Diabetes Mellitus. J Clin Endocrinol Metab 1990; 70: 1594-1602.

[74] Covic AM, Schelling JR, Constantiner M et al. Serum C-Peptide Concentrations Poorly Phenotype Type 2 Diabetic End-Stage Renal Disease Patients. Kidney Intern 2000;58(4):1742-50.

[75] Cavaghan MK, Polonsky KS. Insulin Secretion In Vivo. In: Kahn CR, Weir GC, King GL, Moses AC, Smith RJ, Jacobson AM. Joslin's Diabetes Mellitus. 14a Ed. Boston, MA: Lippincott Williams \& Wilkins; 2005. Cap. 7, P.109-124.

[76] Vendrame F, Zappaterreno A, Dotta F. Markers Of Beta Cell Function In Type 1 Diabetes Mellitus. Minerva Med 2004; 95:1-6.

[77] Tsai EB, Sherry NA, Palmer JP, Herold KC. For The DPT-1 Study Group.The Rise And Fall Of Insulin Secretion In Type 1 Diabetes Mellitus. Diabetologia 2006;49:261-70.

[78] Fujisawa T, Ikegami H, Kawaguchi $Y$ et al. Class I HLA Is Associated With Age-AtOnset Of IDDM, While Class II HLA Confers Susceptibility To IDDM. Diabetologia 1995; 38(12): 1493-1495.

[79] Faber OK, Binder C. C-Peptide Response To Glucagon. Diabetes 1977; 26: 605-610.

[80] Steele C, Hagopian WA, Gitelman S et al. Insulin Secretion In Type 1 Diabetes. Diabetes 2004; 53: 426-433.

[81] Sherry NA, Tsai EB, Palmer JP, Herold KC. Natural History Of Beta Cell Function In Type 1 Diabetes. Diabetes 2005; 54(Suppl 2): 32-39.

[82] Koskinem PJ, Viikari JS, Irjala KMA. Glucagon-Stimulated And Posprandial Plasma CPeptide Values As Measures Of Insulin Secretory Capacity. Diabetes Care 1988; 11(4): 318- 322.

[83] Cernea S, Raz I, Kevan C et al. Challenges In Developing Endpoints For Type 1 Diabetes Intervention Studies. Diabetes Metab Res Rev 2009; 25: 694-704.

[84] Palmer J.P et al. C-Peptide In The Natural History Of Type 1 Diabetes. Diabetes Metab Res Rev 2009; 25(4): 325-328.

[85] Scheen AJ, Castillo MJ, Lefebvre PJ. Assessment Of Residual Insulin Secretion In Diabetic Patients Using The Intravenous Glucagon Stimulatory Test: Methodological Aspects And Clinical Implications. Diabetes Metab 1996; 22: $397-$ 446.

[86] Greenbaum C, Harison IC. Guidelines For Intervention Trials In Subjects With Newly Diagnosed Type 1 Diabetes. Diabetes 2003; 52: 1059-1065.

[87] Palatnik, M et al. Ethnicity And Type 2 Diabetes In Rio De Janeiro, Brazil, With A Review Of The Prevalence Of The Disease In Amerindians. Hum Biol 2002; 74 (4): 533-544. 
[88] Chase HP, Cuthbertson DD, Dolan LM et al. First-Phase Insulin Release During The Intravenous Glucose Tolerance Test As A Risk Factor For Type 1 Diabetes. J Pediatr 2001; 138(2): 244-249.

[89] Keskinen P, Korhonen S, Kupila A et al. First - Phase Insulin Response In Young Healthy Children At Genetic And Immunological Risk For Type 1 Diabetes. Diabetologia 2002; 45(12): 1639-1648.

[90] Meier JJ, Bhushan A, Butler AE et al. Sustained Beta Cell Apoptosis In Patients With Long-Standing Type 1 Diabetes: Indirect Evidence For Islet Regeneration? Diabetologia 2005; 48(11): 2221-8.

[91] Keenan HA, Berger A, Sun JK et al. Demonstration Of Islet Cell Function In Patients With 50 Years Or Longer Of Diabetes. Diabetes 2007;56(S1): 386.

[92] Rodacki M, Milech A, Oliveira JEP. A Secreção Residual Do Peptídeo C Faz Diferença No Tratamento Do Diabetes Melito Tipo 1? Arq Bras Endocrinol Metab 2008; 52(2): 322-333.

[93] Snorgaard O, Larsen LH, Binder C. Homogeneity In Patter Of Decline Of B-Cell Function In IDDM. Diabetes Care 1992; 15: 1009-1015.

[94] Karjalainen J, Salmela P, Ilonen J et al. A Comparison Of Childhood And Adult Type 1 Diabetes. N Engl J Med 1989; 320: 881-886.

[95] Ludvigsson J. The Role Of Immunomodulation Therapy In Autoimmune Diabetes. J Diabetes Sci Technol 2009; 3(2): 320-330.

[96] Ludvigsson J, Faresjö M, Hjorth $\mathrm{M}$ et al. GAD Treatment And Insulin Secretion In Recent-Onset Type 1 Diabetes. N Engl J Med 2008; 359(18): 1909-20.

[97] Kolb H, Gale EA. Does Partial Preservation Of Residual Beta-Cell Function Justify Immune Intervention In Recent Onset Type I Diabetes? Diabetologia 2001; 44(10): 1349-53.

[98] Sjöberg S, Gunnarsson R. Residual Insulin Production, Glycaemic Control And Prevalence Of Microvascular Lesions And Polyneuropathy In Long-Term Type 1 (Insulin-Dependent) Diabetes Mellitus. Diabetologia 1987; 30: 208-213.

[99] Klein R, Moss SE, Klein BE et al. Wisconsin Epidemiologic Study Of Diabetic Retinopathy. XII. Relationship Of C-Peptide And Diabetic Retinopathy. Diabetes 1990; 39(11): 1445-50.

[100] Winocour PH, Jeacock J, Kalsi P et al. The Relevance Of Persistent C-Peptide Secretion In Type 1 (Insulindependent) Diabetes Mellitus To Glycaemic Control And Diabetic Complications. Diabetes Res Clin Pract 1990; 9(1): 23-35.

[101] Gomes MB, Goncalves MF, Neves R et al. Residual Beta-Cell Function And Microvascular Complications In Type 1 Diabetic Patients. Braz J Med Biol Res 2000; 33(2): 211-6.

[102] S Berna P, Valentini U, Cimino A, Sabatti MC, Rotondi A, Crisetig M, Et Al. Residual B-Cell Function In Insulin-Dependent (Typei) Diabetics With And Without Retinopathy. Acta Diabetol Lat 1986; 23(4): 339-44.

[103] Brown RJ, Rother KI. Effects Of Beta-Cell Rest On Beta-Cell Function: A Review Of Clinical And Preclinical Data. Pediatric Diabetes 2008; 9(3): 14-22.

[104] Cernea S, Herold K. Drug Insight: New Immunomodulatory Therapies In Type 1 Diabetes. Nat Clin Pract Endocrinol Metab 2006; 2(2): 89-98.

[105] Herold KC, Hagopian W, Auger JA et al. Anti-CD3 Monoclonal Antibody In NewOnset Type 1 Diabetes Mellitus. N Engl J Med 2002; 346: 1692-98. 
[106] Herold KC, Gitelman SE, Masharani U, et al. A Single Course Of Anti-CD3 Monoclonal Antibody Hokt3gamma1(Ala-Ala) Results In Improvement In CPeptide Responses And Clinical Parameters For At Least 2 Years After Onset Of Type 1 Diabetes. Diabetes 2005; 54(6): 1763-9.

[107] Chéramy M, Skoglund C, Johansson I, Ludvigsson J. GAD-alum treatment in patients with type 1 diabetes and the subsequent effect on GADA IgG subclass distribution, GAD65 enzyme activity and humoral response. Clin Immunol. 2010;137 (1): 31-40.

[108] Ziegler AG, Walter M. Loss And Preservation Of B-Cell Function: Two Treatment Regimes Targeting T Or B Lymphocytes. Diabetologia 2010; 10(5): 323-325.

[109] Lazar L, Ofan R, Weintrob N, et al. Heat-Shock Protein Peptide Dia-pep277 Treatment In Children With Newly Diagnosed Type 1 Diabetes: A Randomised, Double-Blind Phase II Study. Diabetes Metab Res Rev 2007;23(4):286-91.

[110] Raz I, Avron A, Tamir M, et al. Treatment Of New-Onset Type 1 Diabetes With Peptide Dia-Pep277 Is Safe And Associated With Preserved Beta-Cell Function: Extension Of A Randomized, Double-Blind, Phase II Trial. Diabetes Metab Res Rev 2007; 23(4): 292-8.

[111] Voltarelli JC, Couri CE, Stracieri AB, et al. Autologous Nonmyeloablative Hematopoietic Stem Cell Transplantation In Newly Diagnosed Type 1 Diabetes Mellitus. JAMA 2007; 297(14): 1568-76. 


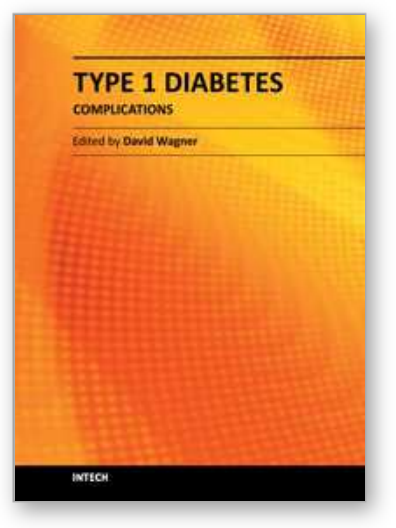

\author{
Type 1 Diabetes Complications \\ Edited by Prof. David Wagner
}

ISBN 978-953-307-788-8

Hard cover, 482 pages

Publisher InTech

Published online 25, November, 2011

Published in print edition November, 2011

This book is a compilation of reviews about the complication of Type 1 Diabetes. T1D is a classic autoimmune disease. Genetic factors are clearly determinant but cannot explain the rapid, even overwhelming expanse of this disease. Understanding etiology and pathogenesis of this disease is essential. The complications associated with T1D cover a range of clinical obstacles. A number of experts in the field have covered a range of topics for consideration that are applicable to researcher and clinician alike. This book provides apt descriptions of cutting edge technologies and applications in the ever going search for treatments and cure for diabetes.

\title{
How to reference
}

In order to correctly reference this scholarly work, feel free to copy and paste the following:

Mirella Hansen De Almeida, Alessandra Saldanha De Mattos Matheus and Giovanna A. Balarini Lima (2011). Understanding Pancreatic Secretion in Type 1 Diabetes, Type 1 Diabetes Complications, Prof. David Wagner (Ed.), ISBN: 978-953-307-788-8, InTech, Available from: http://www.intechopen.com/books/type-1-diabetescomplications/understanding-pancreatic-secretion-in-type-1-diabetes

\section{INTECH}

open science | open minds

\section{InTech Europe}

University Campus STeP Ri

Slavka Krautzeka 83/A

51000 Rijeka, Croatia

Phone: +385 (51) 770447

Fax: +385 (51) 686166

www.intechopen.com

\section{InTech China}

Unit 405, Office Block, Hotel Equatorial Shanghai

No.65, Yan An Road (West), Shanghai, 200040, China

中国上海市延安西路65号上海国际贵都大饭店办公楼 405 单元

Phone: +86-21-62489820

Fax: $+86-21-62489821$ 
(C) 2011 The Author(s). Licensee IntechOpen. This is an open access article distributed under the terms of the Creative Commons Attribution 3.0 License, which permits unrestricted use, distribution, and reproduction in any medium, provided the original work is properly cited. 